\title{
Teacher Understanding in Implementing Curriculum Change in Indonesia
}

\section{Fadhilah Razali}

Faculty of Teacher Training and Education Syiah Kuala University, Darussalam, Banda Aceh, Indonesia

\begin{abstract}
Implementing a new curriculum requires the creativity and independence of teachers. Especially in developing and implementing, it is not easy work to facilitate teachers when they not having a strong understanding and the school does not facilitate this program. Some studies indicated that the initial implementation of curriculum changes does not run effectively as planned. Teachers find that it was difficult to implement curriculum changes in the form of teaching styles. The evidence from studies shows a lack of effort of teachers to implement change. There are various obstacles for teachers to implement curriculum changes. The obstacles indicate the form of weakness in terms of teacher skills and teacher knowledge. In curriculum change, weaknesses are found when the curriculum is prepared by other parties, or not by the teacher who guides the subject. The facts in the field show that not all teachers have the same understanding to compile a new curriculum. The ability of teachers is limited so that problems occur. Therefore, there is a need to pay attention to the understanding of teachers in implementing the curriculum change.
\end{abstract}

Keywords: Teacher Understanding, Skill and Knowledge, Implementation, Curriculum Change

\section{Introduction}

Curriculum and instruction are two things that can't be separated. As a plan or program, the curriculum will not convince when it is not implemented in the form of learning. And vice versa, without starting in the learning components that are articulated in the curriculum. Siraj (2008) claimed that the curriculum is the whole experience gained by each student in an educational program aimed at achieving broader goals and specific objectives that are related and have been designed in the form of a past and present framework.

Learning activities held by teachers are the main part of formal education. It is an absolute requirement that sets the curriculum as a guide. Thus, teachers in designing the program even in implementing the learning process will always be guided by the curriculum. Kelly (2004) mentioned that practical learning in designing curriculum, effective and productive offers a lot of knowledge or lessons in subjects that were taught and transmitted by the school. Further, Naz and Murad (2017) suggested that to encourage innovative teaching, the curriculum needs to undergo comprehensive development, where teachers can adopt different innovative teaching strategies accordingly for the diverse needs of students.

In Indonesia, there have been several changes to the curriculum namely in 1968,1978,1984,1994 and 2004. currently, the curriculum is designed with characters. However, various analyzes indicate that Indonesia's National Adult education is faced with a variety of problems. Data from the United Nations of Educational, Scientific, and Cultural Organization (UNESCO) (2017) found that Indonesia's education quality ranked $10^{\text {th }}$ out of 14 developing countries. Meanwhile, teacher quality as an important component of education ranked 14 out of 14 developing countries. Indeed, this fact is ironic given that education is an indicator of a nation's progress. The fact indicates that teachers as educators do not yet have sufficient professional competence in carrying out their duties and responsibilities as educators. This is a crisis that needs to be addressed as soon as possible, such as teacher's understanding of the implementation of curriculum change. In the new curriculum, the planning implementation of learning by the teacher should have a high level of understanding. The result of a study by Subahan found that teachers have problems understanding how to make such changes. Teachers will not oppose an implementation if the change does not bother the teacher. 


\section{Teacher Understanding of the Curriculum}

The curriculum is a very important tool for the glory of education. Without an appropriate and effective curriculum, it will be difficult to achieve the desired educational goals and objectives. In other words, an appropriate and convenient curriculum can be expected and educational goals will be achieved. To reach the goals, the role of the teacher is very decisive in curriculum issues. Nasution (1995) stated the teacher always represents the main character to realize the curriculum so that changes occur in students as expected. The curriculum is a statement of educational goals that are general and specific in which the material is selected and arranged in a certain pattern for the benefit of learning and teaching. The curriculum as a plan is made to guide children learning in school, is presented in the form of predetermined documents, arranged to include regeneration ratings, can be actualized in class, can be accessed by those who wish, and can be used as a behavior. Thus, it can be stated that the curriculum is a plan and arrangement regarding the objectives, content and learning materials as well as the methods used as guidelines for organizing learning activities to achieve certain educational goals.

The teacher is the main key in the triumph of the curriculum. A teacher who acts as the designer, the actual curriculum implementer. In the future, teachers will face challenges in the learning process. Arends (2008) stated that the work of teachers in the 21 st century is faced with seven major challenges namely (1) teaching and technology (2) teaching with new perspectives on abilities (3) teaching and choosing, (4) teaching and accountability (5) teaching for active learning (6) teaching for fostering meaning, (7) teaching in multicultural societies. Therefore, the teacher is required to be able to act based on thoughtful, independent and collaborative thinking and to contribute to critical demands. Teachers as professional educators are expected to enhance the competencies that they need to support their work as well as face the challenges and advances in science and technology (Arend et al, 2001).

With the challenges faced by teachers, the teacher must be able to make an effective curriculum that will be able to achieve the goals set and targets that have been set. Thus, the teacher is required to have a broad understanding and insight about the curriculum both theoretically as well as practically. Sumantri (1988) asserted that the purpose of the curriculum is not to turn off the teacher's initiative and work, but instead the teacher is seen as someone who shows his creation and adaptation in implementing the curriculum. Miller and Seller (1985) stated that implementation as a process that involves reducing the difference between the statement of practice and the practical expectations of innovation. Implementation is a process of change in behavior that is driven by innovation occurring in stages, periodically and overcoming obstacles in its development. The above understanding provides the understanding that the curriculum in the dimension of activity dimension is a manifestation of the effort to create a curriculum as the written document becoming the latest in a series of learning activities.

Every step in the implementation must take into account the foundation of the curriculum. According to Murray Print (1993), there are influential platforms on the form and mind of curriculum implementers. The three basic principles that should be used are: (1) the foundation of philosophy is to explain concepts that can be used based on understandable knowledge, (2) sociological foundation is social and cultural factors that influence the form of the curriculum, (3) the psychological foundation that observes, describe, predict and consider human behavior.

In implementing the curriculum implementation should be based on the content of the curriculum. There is the assumption that claimed curriculum content as a group of teaching materials. Brady (1992) argued that the content of curriculum (1) curriculum content can be understood as a subject that includes some facts, knowledge, expertise, concepts, attitudes, and values (2) curriculum content is an important part of the process of learning to teach that the two main elements of the curriculum are content and methods of regular interaction. Zais (1976) stated that curriculum content usually consists of three elements namely knowledge, process and value.

Curriculum and intrusion are two inseparable things. As a plan or program, the curriculum is not meaningful when it is not implemented in the form of learning. Similarly, without obvious curriculum as a reference, learning would not be effective. The learning activities organized by each teacher often was begun with the components of learning listed in the curriculum. Siraj (2008) argued that the curriculum is the entire experience gained by each student in an educational program aimed at achieving broader goals and specific 
goals and has been designed in the form of a framework of theory and research or professional practice in the past and the present.

Learning activities by the teacher are an integral part of formal education where the absolute requirement of the curriculum is to be a guide. Thus teachers in designing programs or implementing the learning process will always be in the curriculum. Kelly (2004) mentioned that curriculum planning is practical, effective and productive that offers a wealth of knowledge or subjects that schools teach, serve or transmit.

In the learning activities, all the concepts, principles, values, knowledge, methods, tools and abilities of the teacher are tested in the form of actions that will create a realistic curriculum. The embodiment of the concepts, principles, and aspects of the curriculum rests entirely on the ability of the teacher to implement the curriculum. According to Rusman (2007) the ability that teachers should have in curriculum implementation includes (1) understanding of the goals they want to achieve (2) the ability to structure the curriculum objectives into more specific (3) the ability to translate specific goals into learning objectives.

\section{Curriculum Change}

One of the important components of the education system is the curriculum. It is the component of education that is the focus of every unit of education, both the manager and the organizer, especially the teachers and principals. Therefore, since Indonesia has the freedom, to provide education for its citizens, the government has created a curriculum for educational progress. In this regard, the central government created curriculum centralized and enforced for all nationalities throughout Indonesia's homeland" (E. Mulyana, 2007).

Teachers' understanding of curriculum changes can create obstacles for teachers in their implementation. According to Swetz \& Subahan (1981), these barriers indicate, among others, that there are weaknesses in teacher skills and knowledge. In curriculum change, teachers indicate barriers to making plans for learning, creating modules, using media and using learning models. Siti Hawa (1986) has argued that such a change is considered successful if teachers are ready to accept new ideas and be able to implement them in the classroom.

Some studies showed that in the early stage, implementation of curriculum changes is ineffective. Sukumaran (1998) found that teachers are difficult to implement change in the form of the teaching style of teaching since studies show there is a lack of ability to implement change. In a study of curriculum innovation in Malaysia, Azizah (1987) stated that teachers have difficulty in implementing a studentcentered teaching approach because they do not receive adequate training. Thus, teachers' knowledge of learning design, module, media and learning model needs to receive adequate training.

The general view is that most teachers feel uncomfortable about school reform because they fear that the change will disrupt the solution and affect their responsibility and roles, whether directly related to the teaching and learning process. Habib Mat Som (1985) argued that teachers' readiness to implement reforms is an important issue that educationists need to consider to maintain harmony between the innovators (teachers) and the innovation planners. Authority party considers curriculum reform is an obligation, while teachers see it in the opposite view. No matter how the teacher reacts to the curriculum reforms, however, the changes will continue to occur, even if it is difficult to contain, teachers should have their view of achieving their goals (Sarason, 1991).

A teacher's competence can range from experience and understanding of facts and concepts to motor skills, teaching behavior, and professional values (Lynn \& Nixon, 1985). It is well argued by Katane and Selvi (2006) that competence is a set of knowledge, skills and skills in creating meaningful experiences when organizing an activity. Therefore, Sukmadinata (2002) stated that the main obstacle to the implementation of the curriculum in schools lies in teachers' lack of knowledge and ability of the teachers themselves. Thus, weaknesses are found when the curriculum is set up by others, or not by the teachers who teach as in the preparation of the previous curriculum. It was observed that (1) field facts indicate that not all teachers have the same understanding to implement the curriculum. It is said that the teacher's ability is limited. Therefore, there are often problems and the implementation needs to be done in conjunction with the teacher so that the teacher knows exactly what he is doing. (2) so far as the curriculum has been modified, all parties consider the curriculum to be final, irrevocable. The success of the curriculum is highly dependent on teachers and principals as both are key to moving the school component" (Mulyasa, 2009). 
The curriculum is a statement of general and specific educational goals in which the material is selected and formulated in a specific pattern for the benefit of learning and teaching. Thus, the curriculum is a plan designed to guide students learning in school, presented in predetermined documents, organized by regenerative stages, can be practiced in the classroom, observed by non-stakeholders, and can bring about behavioral change. It can thus be said that the curriculum is a plan and a statement of the purpose, content and materials and how it is used as a guide for organizing learning activities to achieve specific educational goals. A new curriculum requires the commitment of teachers and schools to plan and implement it. Thus, when there is a curriculum change, it is expected to provide adequate training for teachers, so that in practice teachers can play an active role.

\section{Conclusion}

Curriculum change is a common feature to respond to the rapid development of society. A teacher who will implement the new curriculum in the class through the process of learning needs to understand this case. However, the teacher may find it difficult to implement when their understanding of curriculum changes is not as expected. Therefore, The government in Indonesia should facilitate various issues related to curriculum changes. In particular, they need to integrated support of all parties to drive teacher qualification in implement curriculum change. If not, then teachers will not be able to become innovators of education due to they don't have a strong understanding of curriculum change as they assume that curriculum changes will only burden their roles and responsibilities. As such, they will not be able to do much in supporting and implementing curriculum changes. Teachers as users of a new curriculum need to have access to knowledge of training, teaching programs, resources and teaching aids to understand all of this.

\section{References}

[1.] Arends, Richard. (2007). "Learning to Teach", Avenue of the Americans New York, NY 10020: McGraw-Hill Companies, Inc 1221.

[2.] Arends, R. I., Wenitzky, N. E., \& Tannenboum, M. D. (2001). Exploring teaching: An introduction to education. New York: McGraw-Hill Companies.

[3.] Azizah Ab. Rahman, (1987) Curriculum innovation in Malaysia. The case of KBSR. Ph.D University, London.

[4.] Brady, Laurie. (1992). Curriculum development (Third Edition). Australia.Prentice Hall.

[5.] Habib Mat Som, (1985). Guru dan pelaksanaan inovasi kurikulum sorotan dan perbincangan Universiti Malaya. Masalah pendidikan jilid 27.

[6.] Kelly, A.V. (2004). The curriculum theory and practice fifth edition. London. Sage Publications

[7.] Miller, J.P \& Siller, W. (1985). Curriculum: perspective and practices. NewYork: American Book Co.

[8.] Mulyasa, Enco (2008). Implementasi kurikulum tingkat satuan pendidikan. Jakarta. PT. PT. Bumi Aksara

[9.] Naz, F., \& Murad, H. S. (2017). Innovative teaching has a positive impact on the performance of diverse students. SAGE Open, 7(4),

[10.] Nasution, S. (1995). Pengembangan kurikulum. Bandung: PT. Citra Aditya Bakti.

[11.] Print, Murray. (1993). Curriculum development and design. Australia. Allen \& Unwin.

[12.] Rusman, (2009). Manajemen kurikulum. Jakarta. PT. Raja Grafindo Persada, Jakarta.

[13.] Sarason,S, B. (1991) The predictable failure of educational reform : can we change course before it is too late. San francisco : jossey- Bass.

[14.] Subahan Mohd. Meerah, (1999) Dampak penyelidikan pembelajaran sain terhadap perubahan kurikulum. Universiti Kebangsaan Malaysia.

[15.] Sukumaran (1998) Keberkesanan kurikulum ekonomi Azaz pada peringkat Sekolah Menengah: Satu kajian kes, Thesis Dr. Fal. UKM

[16.] Siraj, Saedah. (2008). Kurikulum masa depan. Kuala Lumpur. Universiti Malaya.

[17.] Sukmadinata, Nana Syaodih. (2004). Pengembangan kurikulum teori dan praktek. Bandung. Remaja Rosdakarya. 
[18.] Sumantri, M. (1998). Kurikulum dan pengajaran. Jakarta: Depdikbud. P2LPTK.

[19.] UNESCO (2017). Global Education Monitoring (GEM). Accessed from https://unesdoc.unesco.org. pada tanggal 4 Oktober 2019.

[20.] Zais, Robert S. (1976). Curriculum prinsiples and foundation. London. Heperand Row. 